\title{
Hubungan Antara Citra Raga dengan Persepsi Terhadap Produktivitas Sales Promotion Girls Kosmetik Kecantikan di Kota Denpasar
}

\author{
Ayu Paramita Antari dan David Hizkia Tobing \\ Program Studi Psikologi, Fakultas Kedokteran, Universitas Udayana \\ ayuparamitaantari@yahoo.co.id
}

\begin{abstract}
Abstrak
Semakin meningkatnya penjualan produk kosmetik kecantikan membuat semakin berkembangnya teknik pemasaran dan kebutuhan terhadap tenaga Sales Promotion Girls yang digunakan sebagai ujung tombak dari pemasaran produk kecantikan tersebut. Penampilan fisik yang menarik pada Sales Promotion Girls dapat menarik perhatian konsumen, penampilan fisik tersebut erat hubungannya dengan citra raga dari Sales Promotion Girls. Menurut Konstanski (2007) citra raga seseorang akan berpengaruh kepada kepercayaan dirinya yang menjadi dasar seseorang mengembangkan evaluasi diri terhadap dirinya. Evaluasi diri tersebut akan membentuk persepsi terhadap produktivitas. Berdasarkan hal itu, peneliti tertarik untuk meneliti hubungan antara citra raga dan persepsi produktivitas Sales Promotion Girls produk kecantikan di Kota Denpasar.

Metode penelitian ini merupakan penelitian kuantitatif dan uji hipotesis dilakukan dengan teknik analisis korelasi Pearson's product moment. Subjek pada penelitian ini terdiri dari 110 orang Sales Promotion Girls di Kota Denpasar. Pengumpulan data dilakukan dengan menggunakan dua kuesioner untuk mengukur skala citra raga dan skala persepsi terhadap produktivitas. Item-item pada kuesioner telah diuji validitas dan reliabilitasnya. Pada skala citra raga menunjukkan 27 item yang tidak valid dan 23 item yang valid dengan reliablitas sebesar 0,829 , sedangkan pada skala produktivitas menunjukkan 2 item yang tidak valid dan 23 item yang valid dengan reliabilitas sebesar 0,838 . Berdasarkan analisis data yang diperoleh merupakan data yang linear dan normal, sehingga uji korelasi Pearson's product moment dapat dilakukan.
\end{abstract}

Berdasarkan hasil penelitian diperoleh koefisien korelasi antara dua variabel tersebut adalah 0,491 dengan taraf signifikansi 0,000. Maka dapat disimpulkan bahwa terdapat hubungan yang signifikan antara citra raga dengan persepsi terhadap produktivitas Sales Promotion Girls kosmetik produk kecantikan di Kota Denpasar.

Kata kunci: Citra Raga, Persepsi Produktivitas, Sales Promotion Girls

\begin{abstract}
The increasing sales of cosmetics beauty products make the product marketing technique expanding and many sales promotion girl are employed to be important part in promoting women beauty product. Attractive physical appearance in sales promotion girls will draw consumer attention to them. Physical appearance itself correlates with body image in sales promotion girls. According Konstanski (2007) body image will be affected to self confidence. Self confidence makes a person develop self-evaluation. The self-evaluation will shape perceptions of productivity. According to that, researcher wants to find relationship between body image and perception of productivity in sales promotion girls of beauty product in Denpasar City.
\end{abstract}

Method in this research is correlational study. Subjects in this research are 110 sales promotion girls in Denpasar City. Data are collected by body image scale and perception of productivity scale. Test of item validity in body image scale shows there are 27 invalid items and 23 valid items from 50 items, and its reliability coefficient is 0,829 . Test of item validity in perception of productivity scale shows there are 2 invalid items and 23 valid items from 25 items, and its reliability coefficient is 0,838 . Data analysis shows data are normal and linear. Pearson's product moment is run for data analysis.

Coefficient of correlation between body image and productivity is 0,49 in significance level 0,05 . It means that hypothesis in this research that states there is relationship between body image and perception of productivity in sales promotion girls of beauty product in Denpasar City is accepted.

Keyword: body image, perception of productivity, sales promotion girls 


\section{LATAR BELAKANG}

Pada tahun 2010, peningkatan dalam penjualan kosmetik kecantikan di Indonesia sebesar $11 \%$ lebih besar daripada penjualan barang konsumsi lainnya. Berdasarkan nilai penjualan, dalam triwulan pertama 2010 terdapat kenaikan nilai penjualan produk kecantikan sebesar 14,1\% dibandingkan dengan triwulan pertama tahun sebelumnya (Topan, 2010). Jika dinilai lebih jauh dari penjualan kosmetik kecantikan, nilai penjualan merek premium pelembab dan pembersih wajah, terdapat kenaikan sebesar $18 \%$ (untuk pelembab) dan $15 \%$ (untuk pembersih wajah). Untuk merek menengah, ada kenaikan sebesar $6 \%$ untuk jenis pelembab, sedangkan untuk pembersih turun sebesar 1\% (Saptowalyono, 2012).

Sejalan dengan berkembangnya penjualan produk kecantikan, sistem jual beli di kalangan masyarakat juga telah semakin beragam. Perkembangan pemasaran suatu produk bukan hanya dengan menggunakan cara konvensional dengan perantara agen dan konsumen, namun sistem pemasaran telah berkembang lebih luas melalui berbagai cara. Salah satu cara yang sering digunakan dalam penjualan suatu produk adalah dengan berinteraksi langsung dengan konsumen. Dari data yang telah dipaparkan sebelumnya bahwa penjualan produk kecantikan dan sistem pemasaran di Indonesia semakin meningkat, maka kebutuhan akan tenaga Sales Promotion Girls dalam melakukan penawaran kepada konsumen juga semakin dibutuhkan.

Sales Promotion Girl (SPG) merupakan seorang perempuan yang menjadi ujung tombak dari pemasaran suatu produk atau sebagai salah satu bagian yang memasarkan langsung produk maupun sampel dari produk tersebut kepada konsumen (Raharti, 2001). SPG bertugas langsung berhadapan dengan konsumen yang membeli produk yang ditawarkan. SPG dalam mempromosikan suatu produk memerlukan beberapa keterampilan seperti bahasa tubuh, komunikasi dan penampilan fisik, sehingga sering kali seorang SPG menggunakan penampilan fisik mereka untuk menarik perhatian dari calon pembeli. Secara umum dapat dilihat bahwa seorang SPG selalu menggunakan kecantikan fisik sebagai strategi pemasaran utama mereka untuk mendapatkan perhatian dari konsumen baik dengan alasan pribadi maupun memang suatu keharusan dari perusahaan. Hal tersebut sering kali mengundang pandangan yang kurang baik di masyarakat, karena label yang telah diberikan masyarakat umum kepada SPG identik dengan perempuan muda yang menggunakan pakaian di luar norma atau aturan sosial, pakaian-pakaian yang kurang sopan seperti baju tanpa lengan atau rok mini yang menampilkan lekuk tubuh mereka (Retnaningsih, 2001).

Terdapat beberapa kriteria umum yang ditetapkan perusahaan dalam merekrut seseorang sebagai SPG, yakni, performance yang merupakan tampilan fisik yang dapat dinilai dengan indra penglihatan, communicating style yaitu dengan ${ }_{s}$ melalui komunikasi akan tercipta interaksi antara SPG dengan konsumen, dan body language yang mengarah pada gerakan fisik (Raharti, 2001). Pada iklan-iklan lowongan pekerjaan sebagai SPG sering kali mencantumkan penampilan fisik yang menarik seperti cantik dan memiliki tubuh yang ideal sebagai salah satu syarat. Pada umumnya, SPG memiliki penampilan yang enak dipandang oleh mata sehingga konsumen dapat tertarik dengan produk yang ditawarkan. Terutama pada SPG yang menjual perlengkapan kecantikan pada perempuan, penampilan fisik dari SPG itu sangat diperlukan untuk menarik pelanggan. SPG pada produk kecantikan perempuan akan menjadi representasi produk yang mereka jual kepada konsumen (Retnaningsih, 2001).

Citra raga adalah sikap yang dimiliki seseorang terhadap tubuhnya yang dapat berupa penilaian positif atau negatif (Cash \& Pruzinsky dalam Thompson, 1999). Eating Disorder Awareness and Prevention atau yang disingkat dengan EDAP (dalam Small 2001) menyatakan bahwa seseorang yang citra raganya positif, memiliki persepsi yang jelas dan benar tentang bentuk tubuh, dan menghargai bentuk tubuh itu. Citra Raga yang merupakan suatu pandangan subjektif yang dapat pula menimbulkan kontradiksi, dimana seseorang yang terlihat tampil ideal mungkin saja memiliki citra raga yang negatif (Honigman dan Castle, 2006). Dalam penelitian yang dilakukan oleh Elmer (2010), seseorang yang menarik adalah seseorang yang percaya bahwa dirinya menarik dan memiliki citra raga yang positif, namun seseorang yang tidak menarik dapat menjadi menarik apabila memiliki citra raga yang positif dan menerima penampilan dirinya. Citra raga yang positif akan berpengaruh pada kepercayaan diri seseorang (Kostanski, 2007). Kepercayaan diri yang dimiliki membuat seseorang akan mengembangkan evaluasi diri terhadap dirinya. Evaluasi diri tersebut akan membentuk persepsi terhadap produktivitas seseorang.

Persepsi itu sendiri berarti suatu interpretasi atau penilaian terhadap lingkungan sekitar atau keadaan di sekitar individu (Kalat, 2009). Menurut W. R. Nord (dalam Gibson, 1987) menyatakan bahwa persepsi adalah proses pemberian arti terhadap lingkungan oleh individu. Persepsi juga merupakan faktor yang menentukan terbentuknya sikap terhadap sesuatu maupun perilaku tertentu. Dari beberapa pendapat yang menjelaskan tentang pengertian persepsi, dapat disimpulkan bahwa persepsi merupakan suatu proses pengenalan maupun proses pemberian arti terhadap apa yang dirasakan oleh seorang individu.

Produktivitas adalah rasio antara hasil kegiatan (output) dengan segala pengorbanan (input) dalam menghasilkan barang produksi (Nasution, 2004). Dalam perspektif normatif, pengertian produktivitas adalah jika hari ini karyawan lebih baik daripada kemarin dan hari esok lebih baik daripada sekarang. Jadi, dari beberapa penjelasan tentang persepsi dan produktivitas, maka dapat disimpulkan bahwa 
persepsi terhadap produktivitas adalah penafsiran individu terhadap hasil kerja (output) yang dapat ia tunjukkan., sedangkan produktivitas adalah rasio antara hasil kegiatan (output) dengan segala pengorbanan (input) dalam menghasilkan barang produksi (Nasution, 2004). Jadi, persepsi terhadap produktivitas adalah penafsiran individu terhadap hasil kerja (output) yang dapat ia tunjukkan.

Pada konteks SPG, mereka yang memiliki citra raga positif, kepercayaan dirinya cenderung akan meningkat dimana hal itu akan mengakibatkan adanya evaluasi terhadap diri SPG. Evaluasi diri pada SPG tersebut menghasilkan persepsi terhadap produktivitas kerjanya, yang dalam hal ini yaitu penjualan produk kosmetik kecantikan. Oleh karena itu, peneliti berasumsi bahwa ada hubungan antara citra raga dengan persepsi terhadap produktivitas SPG produk kosmetik kecantikan.

Berdasarkan pemaparan diatas, pada penelitian ini peneliti tertarik melihat hubungan antara citra raga dengan persepsi terhadap produktivitas penjualan pada SPG kosmetik kecantikan.

\section{METODE}

\section{Hipotesis}

Berdasarkan penjelasan yang telah diuraikan di latar belakang, peneliti mengajukan hipotesis"ada hubungan antara citra raga dengan persepsi terhadap produktivitas Sales Promotion Girls produk kosmetik kecantikan di Kota Denpasar".

\section{Variabel dan definisi operasional}

Variabel adalah simbol yang nilainya dapat bervariasi, yaitu angkanya dapat berbeda-beda dari satu subjek ke subjek yang lain atau dari satu objek ke objek yang lain (Azwar, 2010). Penelitian ini membedakan variabel menjadi dua yaitu variabel bebas dan variabel tergantung. Variabel bebas adalah suatu variabel yang variasinya mempengaruhi variabel lain, dapat pula dikatakan bahwa variabel yang pengaruhnya terhadapt variabel lain ingin diketahui (Azwar, 2010). Variabel bebas dalam penelitian ini adalah citra raga. Sedangkan variabel terikat adalah variabel yang dipengaruhi oleh variabel bebas (Azwar, 2010). Variabel tergantung pada penelitian ini adalah persepsi terhadap produktivitas.

Berikut ini adalah definisi operasional masingmasing variabel:

1. Definisi operasional citra raga

Citra raga merupakan penilaian seseorang terhadap penampilan dirinya untuk dihadapkan dan ditunjukkan kepada orang lain. Citra raga dalam penelitian ini diukur menggunakan skala yang disusun oleh peneliti berdasarkan beberapa aspek yaitu, evaluasi penampilan, orientasi penampilan, kepuasan area tubuh, kecemasan menjadi gemuk dan pengkategorian ukuran tubuh yang dikemukakan oleh Chas (2005). Citra raga akan diukur dengan kuesioner yang berisi tentang pernyataan yang berkaitan dengan Citra Raga. Pernyataan dalam kuesioner yang akan diisi oleh subjek adalah pernyataan yang disesuikan dengan aspek Citra Raga yang telah dijelaskan diatas. Terdapat empat alternatif jawaban, yakni yakni 'sangat tidak setuju', 'tidak setuju', 'setuju', dan 'sangat setuju', yang nantinya diberi skor berdasarkan tipe pernyataan (favorabel atau non favorabel). Skor total pada skala citra raga merupakan petunjuk gambaran tubuh yang positif dan negatif. Skor Citra raga yang tinggi berarti bahwa seseorang memiliki citra raga yang positif dan skor citra raga yang rendah berarti seseorang memiliki citra tubuh yang negatif.

2. Definisi operasional persepsi terhadap produktivitas Persepsi produktivitas adalah suatu proses pemberian arti maupun proses penafsiran individu terhadap hasil kerja (output) yang dapat ia tunjukkan baik dalam bentuk material maupun non material. Dimana persepsi produktivitas SPG dalam penelitian ini dapat dinilai dari beberapa aspek yaitu, persepsi terhadap omset penjualan, persepsi terhadap pemahaman produk, persepsi terhadap kemampuan promosi, dan persepsi terhadap kemampuan komunikasi. Persepsi produktivitas akan diukur dengan kuesioner yang berisi tentang pernyataan yang berkaitan dengan persepsi produktivitas SPG. Pernyataan dalam kuesioner yang akan diisi oleh SPG adalah pernyataan yang disesuaikan dengan aspek persepsi produktivitas yang telah dijelaskan diatas. Terdapat empat alternatif jawaban, yakni yakni 'sangat tidak setuju', 'tidak setuju', 'setuju', dan 'sangat setuju', yang nantinya diberi skor berdasarkan tipe pernyataan (favorabel atau non favorabel).

\section{Subjek penelitian}

Subjek dipilih melalui teknik simple random sampling dari populasi berupa SPG di Bali. Dalam penelitian ini, subjek yang digunakan adalah SPG yang khusus menjual produk kosmetik kecantikan. Jumlah dari subjek ditentukan dengan rumus perhitungan populasi yang tidak diketahui sehingga subjek yang digunakan dalam penelitian ini adalah sebanyak 110 subjek.

\section{Tempat penelitian}

Penelitian ini diadakan di pusat perbelanjaan besar di Kota Denpasar, pada bulan Januari tahun 2013. 
Alat ukur

Alat ukur dalam penelitian ini adalah kuesioner. Terdapat dua kuesioner yang akan digunakan dalam penelitian ini yakni kuesioner citra raga dan kuesioner persepsi terhadap produktivitas. Semua kuesioner akan disusun oleh peneliti dan diuji reliabilitas dan validitasnya.

Kuesioner akan diberikan tercantumkan petunjuk dan contoh pengisian kuesioner. Subjek diminta untuk memilih salah satu dari empat alternatif jawaban dengan sebelumnya diingatkan bahwa tidak terdapat jawaban yang benar maupun salah. Kuesioner yang digunakan adalah kuesioner dengan bentuk pertanyaan tertutup. Pada penelitian menggunakan skala Likert.

Jawaban item skala Likert merupakan gradasi dari sangat positif sampai sangat negatif yang dapat berupa katakata: sangat setuju, setuju, tidak setuju dan sangat tidak setuju.

Validitas yang ditinjau dalam penelitian ini adalah validitas konstruk. Reliabilitas diuji dengan pendekatan konsistensi internal. Validitas konstruk diuji dengan melihat nilai rix (corrected item-total correlation) dengan batas toleransi 0,30. Pengujian reliabilitas konsistensi internal dilakukan dengan menggunakan teknik Cronbach's alpha dibantu program SPSS 17.

Setelah melalui tahap pengujian validitas dan reliabilitas tersebut, ditemukan bahwa kuesioner citra raga memiliki 23 item sahih dengan koefisien reliabilitas 0,829 dan kuesioner pelanggaran persepsi terhadap produktivitas memiliki 23 item sahih dengan koefisien reliabilitas 0,838 .

\section{Metode pengumpulan data}

Dalam penelitian ini, pengumpulan data dilakukan dengan cara melakukan pengukuran terhadap dua variabel penelitian, yaitu citra raga, dan persepsi terhadap produktivitas. Seluruh variabel diukur dengan kuesioner. Pengumpulan data dilakukan dengan menyebarkan kuesioner ke 110 orang SPG di pusat perbelanjaan besar di Kota Denpasar, sampel dalam penelitian ini melalui simple random sampling dari populasi berupa SPG di Kota Denpasar.

\section{Teknik analisis data}

Secara spesifik, penelitian ini merupakan bentuk studi korelasional dengan metode analisis analisis parametrik menggunakan korelasi Pearson's product moment. Analisis korelasi Pearson's product moment digunakan untuk melihat hubungan antar variabel citra raga dan variabel persepsi terhadap produktivitas. Analisis data dilakukan dengan menggunakan program bantu SPSS 17.
HASIL PENELITIAN

Sebelum melihat apakah terdapat hubungan antara variabel-variabel yang ingin diteliti, peneliti melakukan uji asumsi yang meliputi uji normalitas dan uji linearitas untuk memastikan bahwa data memang layak dan bisa digunakan dalam penelitian.

Dalam penelitian ini, uji normalitas dilakukan dengan menggunakan Kolmogorov-Smirnov SPSS 17. Suatu data dapat dikatakan normal apabila hasil uji normalitasnya berada di atas taraf signifikansi 0,05. Hasil pengujian dapat dilihat pada tabel berikut :

Tabel 1

Hasil Uji Normalitas

\begin{tabular}{|l|r|r|}
\hline & Citra Raga & $\begin{array}{l}\text { Persepsi terhadap } \\
\text { Produktivitas }\end{array}$ \\
\hline $\mathrm{N}$ & 110 & 110 \\
Kolmogrorov-Smirnov Z & .760 & .851 \\
Asymp. Sig. (2-tailed) & .611 & .465 \\
& & \\
\hline
\end{tabular}

Seluruh variabel memiliki taraf signifikansi di atas 0,05 , sehingga semua variabel dinyatakan memiliki distribusi data normal. Selain itu, dilakukan pula uji linearitas untuk melihat apakah hubungan antara satu variabel dependen dengan variabel independen bersifat linear. Asumsi linearitas dapat diuji menggunakan compare means dengan SPSS 17. Apabila signifikansinya berada di bawah taraf signifikansi 0,05 , maka hubungannya dinyatakan linear.

Tabel 2

Hasil Uji Linearitas Citra Raga dan Persepsi Terhadap Produktivitas

\begin{tabular}{|ll|r|r|}
\hline & \multicolumn{1}{|c|}{ F } & \multicolumn{1}{c|}{ Sig. } \\
\hline itptot $*$ Between Groups (Combined) & 2.663 & .000 \\
itctot & Linearity & 38.751 & .000 \\
& Deviation from & 1.460 & .094 \\
& Linearity & & \\
& Within Groups & & \\
& Total & & \\
\hline
\end{tabular}

Analisis data dari tabel uji 2. linearitas ini menunjukkan bahwa hubungan kedua variabel bersifat linear karena probabilitas (p) sebesar 0,000 atau memiliki taraf signifikansi lebih kecil dibandingkan 0,005 ( $\mathrm{p}<0,005)$, sehingga diperoleh hubungan antara citra raga dan persepsi terhadap produktivitas menunjukkan garis yang sejajar.

Hubungan citra raga dengan persepsi terhadap produktivitas dilihat dengan korelasi Pearson's product moment dengan bantuan SPSS 17. Berikut adalah hasil dari uji korelasi Pearson's product moment: 
Tabel 3

Hasil Korelasi Pearson's product moment

\begin{tabular}{|c|c|c|c|}
\hline \multicolumn{4}{|c|}{ Correlations } \\
\hline & & itctot & Itptot \\
\hline \multirow[t]{3}{*}{ itctot } & Pearson Correlation & 1 & $.491^{* *}$ \\
\hline & Sig. (2-tailed) & & .000 \\
\hline & $\mathrm{N}$ & 110 & 110 \\
\hline \multirow[t]{3}{*}{ itptot } & Pearson Correlation & $.491^{* *}$ & 1 \\
\hline & Sig. (2-tailed) & .000 & \\
\hline & $\mathrm{N}$ & 110 & 110 \\
\hline \multicolumn{4}{|c|}{$\begin{array}{l}\text { **. Correlation is significant at the } 0.01 \text { level (2-tailed). } \\
\text { Keterangan }\end{array}$} \\
\hline \multicolumn{4}{|c|}{ Itctot: Variabel Citra Raga } \\
\hline Itptot & bel Persepsi terhad & & \\
\hline
\end{tabular}

Diketahui dari tabel 3 diperoleh nilai koefisien korelasi (r) sebesar 0,491. Angka korelasi yang diperoleh memiliki nilai (+) 0,491 menunjukkan adanya hubungan antara variabel citra raga dan variabel persepsi terhadap produktivitas. Sehingga dapat disimpulkan bahwa kedua variabel saling memiliki hubungan atau saling berkorelasi. Koefisien determinasi menunjukkan besarnya peran atau sumbangan yang dapat diberikan oleh variabel bebas kepada variabel tergantung. Dalam penelitian ini, sumbangan dari variabel citra raga terhadap variabel persepsi terhadap produktivitas sebesar $24,1 \%$, sedangkan sumbangan dari variabel lain selai variabel citra raga adalah $75,9 \%$.

Dari tabel 3. uji korelasi diatas juga dapat dilihat nilai angka probabilitas (p) dari variabel citra raga dan variabel persepsi terhadap produktivitas yaitu sebesar 0,000. Dimana angka tersebut mencerminkan $\mathrm{p}<0,05$ yang berarti $\mathrm{H} 0$ ditolak dan Ha diterima yang menyatakan "Ada hubungan antara citra raga dengan persepsi terhadap produktivitas penjualan SPG produk kosmetik kecantikan". Jadi dapat ditarik kesimpulan bahwa ada hubungan yang signifikan antara citra raga dengan persepsi terhadap produktivitas penjualan SPG produk kosmetik kecantikan.

Peneliti juga melakukan pengkategorisasian skor untuk menambah hasil dalam analisis data penelitian. Kategorisasi dilakukan untuk melihat subyek yang memiliki skor paling tinggi dan rendah pada masing-masing variabel. Penggolongan ini bertujuan untuk menempatkan subyek ke dalam kelompok yang terpisah secara berjenjang menurut kontinum berdasarkan atribut yang diukur (Azwar, 2010). Tabel 4

Rumus Kategorisasi Skor

\begin{tabular}{|c|c|}
\hline Skor & Kategorisasi \\
\hline $\mathrm{X} \leq(\mu-1,5 \sigma)$ & Sangat Rendah \\
$(\mu-1,5 \sigma)<\mathrm{X} \leq(\mu-0,5 \sigma)$ & Rendah \\
$(\mu-0,5 \sigma)<\mathrm{X} \leq(\mu+0,5 \sigma)$ & Sedang \\
$(\mu+0,5 \sigma)<\mathrm{X} \leq(\mu+1,5 \sigma)$ & Tinggi \\
$(\mu+1,5 \sigma)<\mathrm{X}$ & Sangat Tinggi \\
\hline
\end{tabular}

Dengan panduan rumus tersebut, peneliti mengkategorikan skor tiap variabel dalam penelitian ini. Variabel citra raga memiliki skor minimal 23 dan skor maksimal 92, dengan rentang skor 69. Standar deviasinya adalah sebesar 11,5 dengan mean teoritis sebesar 57,5. Hasil kategorisasinya adalah sebagai berikut:

Tabel 5

Hasil Kategorisasi Variabel Citra Raga

\begin{tabular}{|c|c|c|c|c|}
\hline Variabel & Rentang Nilai & Kategori & Subjek & Persentase (\%) \\
\hline Citra Raga & $\begin{array}{c}\mathrm{X} \leq 40,25 \\
40,25<\mathrm{X} \leq 51,75 \\
51,75<\mathrm{X} \leq 63,25 \\
63,25<\mathrm{X} \leq 75 \\
75<\mathrm{X}\end{array}$ & $\begin{array}{l}\text { Sangat Negatif } \\
\text { Negatif } \\
\text { Netral } \\
\text { Positif } \\
\text { Sangat Positif }\end{array}$ & $\begin{array}{c}- \\
1 \\
21 \\
68 \\
20\end{array}$ & $\begin{array}{c}0 \\
9 \% \\
19,1 \% \\
61,8 \% \\
18,2 \%\end{array}$ \\
\hline \multicolumn{3}{|c|}{ Jumlah } & 110 & $100 \%$ \\
\hline
\end{tabular}

Analisis kategorisasi variabel citra raga jumlah subjek yang berada pada rentang sangat negatif adalah 0 orang, negatif sebanyak 1 orang, netral sebanyak 21 orang, positif sebanyak 68 orang dan sangat positif sebanyak 20 orang.

Variabel persepsi terhadap produktivitas memiliki skor minimal 23 dan skor maksimal 92, dengan rentang skor 69. Standar deviasinya adalah sebesar 11,5 dengan mean teoritis sebesar 57,5. Hasil kategorisasinya adalah sebagai berikut:

Tabel 6

Hasil Kategorisasi Variabel Persepsi Terhadap Produktivitas

\begin{tabular}{|c|c|c|c|c|}
\hline Variabel & Rentang Nilai & Kategori & Subjek & Persentase (\%) \\
\hline Persepsi & $\mathrm{X} \leq 40,25$ & Sangat Rendah & - & 0 \\
terhadap & $40,25<\mathrm{X} \leq 51,75$ & Rendah & - & 0 \\
produktivitas & $51,75<\mathrm{X} \leq 63,25$ & Sedang & 5 & $4,5 \%$ \\
& $63,25<\mathrm{X} \leq 75$ & Tinggi & 57 & $51,8 \%$ \\
& $75<\mathrm{X}$ & Sangat Tinggi & 48 & $43,6 \%$ \\
& & & 110 & $100 \%$ \\
\hline
\end{tabular}

Analisis kategorisasi variabel persepsi terhadap produktivitas diketahui jumlah subjek yang berada pada rentang sangat rendah dan rendah adalah 0 orang atau tidak ada. Sedangkan yang berada pada rentang sedang sebanyak 5 orang, pada rentang tinggi sebanyak 57 orang dan pada rentang sangat tinggi sebanyak 48 orang.

\section{PEMBAHASAN}

Hasil penelitian yang dilakukan menunjukan hipoteis alternatif yang berbunyi "Ada hubungan antara citra raga dengan persepsi terhadap produktivitas SPG produk kosmetik kecantikan di Kota Denpasar" diterima. Penerimaan hipotesis ini didasarkan pada hasil dari analisis statistik yang menggunakan analisis korelasi Pearson's product moment, yaitu terdapat hubungan yang cukup kuat antara citra raga dengan persepsi terhadap produktivitas SPG produk kecantikan kosmetik dilihat dari nilai signifikansi sebesar 0,000. Dimana angka tersebut mencerminkan $\mathrm{p}<0,05$ yang berarti Hipotesis Nol ditolak dan Hipotesis Alternatif diterima 
yang artinya "Ada hubungan antara citra raga dengan persepsi terhadap produktivitas penjualan SPG produk kosmetik kecantikan". Selain itu, angka korelasi yang diperoleh memiliki nilai (+) 0,491 menunjukkan adanya hubungan antara variabel citra raga dan variabel persepsi terhadap produktivitas. Sehingga dapat disimpulkan bahwa kedua variabel saling memiliki hubungan atau saling berkorelasi. Koefisien determinasi $\left(\mathrm{r}^{2}\right)$ diperoleh dengan mengkuadratkan nilai $r \quad(0,491)$ sehingga didapat nilai $\mathrm{r}^{2}$ sebesar 0,241. Koefisien determinasi menunjukkan bahwa variabel citra raga berpengaruh $24,1 \%$ terhadap peroduktivitas penjualan pada SPG produk kosmetik kecantikan.

Menurut Ravianto (1990), persepsi terhadap produktivitas dipengaruhi oleh beberapa faktor yaitu: Pendidikan dan pelatihan, fisik dan biologis serta harapan karyawan dan perusahaan. Kontribusi variabel citra raga sebesar 24,1 \% dianggap cukup kuat kontribusinya oleh peneliti, karena banyaknya faktor-faktor lain baik yang mempengaruhi persepsi terhadap produktivitas penjualan dan promosi. Terdapat $75,9 \%$ faktor lain yang mempengaruhi variabel persepsi terhadap produktivitas yaitu tingkat pendidikan dan pelatihan serta harapan karyawan dan perusahaan. Tingkat pendidikan dan pelatihan adalah persepsi individu terhadap pendidikan yang dimiliki baik hasil dari pendidikan formal dan non formal yang memberikan kontribusi seseorang terhadap pemecahan masalah, daya cipta seseorang. Seseorang dengan pengetahuan yang luas dan pendidikan yang tinggi akan membuat seseorang mengevaluasi diri dengan positif dan bekerja lebih poduktif sedangkan harapan karyawan dan perusahaan yaitu harapan karyawan difokuskan pada pemenuhan kebutuhan dirinya sendiri dan keluarga. Harapan perusahaan merupakan harapan kepada karyawan yang tidak selalu searah dengan harapan karyawan sendiri. Harapan perusahaan dalam banyak hal, berbeda dengan harapan karyawan. Perpaduan antara dua macam harapan ini akan menentukan besar kecilnya nilai produktivitas Ravianto (1990). Citra raga merupakan faktor fisik dari SPG yang meliputi motivasi dan kemauan dari SPG itu sendiri untuk meningkatkan performanya dalam bekerja.

Penelitian ini sejalan dengan hasil penelitian dari Wiasti (2011) "Redefinisi Kecantikan dalam meningkatkan persepsi terhadap produktivitas kerja perempuan Bali, di kota Denpasar" dengan kesimpulan konsep kecantikan pada perempuan Bali dibentuk dari kebudayaan serta didukung oleh media masa yang menampilkan kecantikan secara fisik. Hal tersebut akan memiliki pengaruh pada persepsi terhadap produktivitas kerja dari perempuan Bali tersebut. Begitu juga dengan penelitian yang dikemukakan oleh Sachsida, Dornelles, dan Mesquita (2005) "Beauty and the Labor Market-Study one Spesific Occupation”. Penelitian Sachsida (2005) memiliki tujuan mengetahui pengaruh dari penampilan fisik terhadap penjualan pada Sales Promotion Girls di
Brassilia's Shopping Malls, dengan penemuan bahwa seseorang karyawan yang memiliki penampilan yang menarik menerima bonus $9 \%$ lebih besar daripada yang biasa mereka dapatkan, namun bonus ini dihubungkan dengan produktivitas dan tidak ada hubungannya dengan diskriminasi. Hasil yang didapatkan ini terlihat bahwa penampilan yang menarik berhubungan dengan produktivitas pada karyawan. Penelitian ini sejalan dengan penelitian yang dilakukan oleh Sacshida dan Wiasti, dimana citra raga memiliki pengaruh dan hubungan yang erat pada beberapa aspek, termasuk pada peningkatan produktivitas dalam bekerja.

Menurut Cash dan Pruzinsky (dalam Thompson dkk, 1999) citra raga merupakan sikap yang dimiliki seseorang terhadap tubuhnya yang dapat berupa penilaian positif dan negatif. Pada penelitian ini, 110 subjek yang terlibat menjadi sampel dalam penelitian ini sebanyak $80 \%$ memiliki citra raga yang positif dan sangat positif. Sehingga dapat terlihat bahwa sebagian besar SPG cenderung memandang citra raga sebagai suatu hal yang penting untuk menunjang penampilan mereka, namun tidak terlalu membuat citra raga menjadi hal utama dalam mempengaruhi persepsi terhadap produktivitas kerja mereka. Walaupun dari hasil penelitian yang dilakukan sebanyak $80 \%$ SPG memiliki citra raga positif, namun terdapat $20 \%$ dari subjek yang masih memiliki citra raga yang tergolong netral dan negatif, sehingga beberapa pelatihanpelatihan motivasi yang dapat meningkatkan citra raga masih sangat perlu dilakukan.

Seiring dengan hasil dari kuesioner citra raga yang tinggi, subjek pada penelitian ini sebagian besar juga memiliki persepsi terhadap produktivitas yang tinggi yaitu sebanyak 95,4 \%. Dari analisis korelasi yang telah dilakukan, angka probabilitas yang diperoleh peneliti dari hasil analisis korelasi Pearson's product moment adalah 0,000. Hasil ini menunjukkan terdapat hubungan yang signifikan antara variabel citra raga dengan variabel persepsi terhadap produktivitas karena $\mathrm{p}<0,05$, yang memiliki arti bahwa variabel citra raga dan variabel persepsi terhadap produktivitas berkorelasi positif secara signifikan. Hubungan positif yang signifikan dapat diartikan bahwa semakin tinggi citra raga yang dimiliki SPG, maka akan semakin tinggi pula persepsi terhadap produktivitas penjualan yang ditunjukkan oleh SPG tersebut.

Citra raga memiliki pengaruh pada orientasi penampilan. Citra raga yang merupakan konsep negatif dan positif juga akan berpengaruh pada kepercayaan diri individu. Citra raga yang positif akan berpengaruh pada kepercayaan diri seseorang (Kostanski, 2007).

Pada seorang SPG kepercayaan diri akan berhubungan dengan persepsi terhadap produktivitas pada kegiatan penjualan dan promosi pada SPG. SPG bertugas langsung berhadapan dengan konsumen yang membeli produk yang ditawarkan. Kegiatan promosi serta penjualan memerlukan kepercayaan 
diri yang tinggi dari SPG itu sendiri, hal tersebut tidak terlepas dari citra raga yang mempengaruhi persepsi terhadap produktivitas yang akan ditampilkan (Prickett, 2007). Apabila SPG mempunyai citra raga yang positif, maka kepercayaan dirinya akan meningkat. Citra raga yang positif adalah apabila seseorang percaya bahwa dirinya menarik, dan dapat menerima penampilan dirinya apa adanya dan bersyukur akan penampilan yang ia miliki. Kepercayaan diri pada SPG dapat membuat SPG mengevaluasi dirinya secara positif. Evaluasi diri yang positif ini akan membentuk persepsi terhadap produktivitas yang positif pula, sebaliknya apabila SPG memiliki citra raga yang negatif, kepercayaan dirinya akan rendah dan berdampak pada evaluasi negatif terhadap diri sendiri yang membuatnya memiliki persepsi yang negatif terhadap produktivitasnya (Dadang,2012).

SPG yang memiliki citra raga yang positif merupakan SPG yang memiliki kepercayaan diri yang tinggi serta kenyamanan akan dirinya sendiri sehingga hal tersebut membuat seorang SPG yang memiliki citra raga yang positif tidak akan raguragu untuk mengeluarkan semua kemampuannya untuk meningkatkan persepsi terhadap produktivitas. Selain itu SPG yang memiliki citra raga yang positif juga akan terus menggali kemampuan dan potensi-potensi yang dimiliki.

Jadi, dapat disimpulkan bahwa terdapat hubungan positif yang signifikan antara citra raga dengan persepsi terhadap produktivitas, Hipotesis ini dilihat berdasarkan signifikansi pada hasil analisis korelasi Pearson's product moment menunjukkan hasil 0,000 , sehingga memiliki nilai lebih keci dari $0,05(\mathrm{p}<0,05)$ sehingga dapat disimpulkan bahwa variabel citra raga dan variabel persepsi terhadap produktivitas memiliki hubungan yang signifikan. Besar hubungan ditunjukan oleh nilai koefisien 0,491 yang tergolong cukup besar sesuai dengan kategori Usman (2000). Dari uji statistik yang telah dilakukan dapat dinyatakan bahwa secara umum citra raga memiliki hubungan yang cukup kuat dengan persepsi terhadap produktivitas, serta citra raga memberi sumbangan sebesar $24,1 \%$ terhadap persepsi terhadap produktivitas dan $75,9 \%$ persepsi terhadap produktivitas dipengaruhi oleh faktor yang lain.

Dari hasil penelitian yang didapatkan terdapat beberapa saran yang dapat menjadi suatu pertimbangan, Bagi SPG disarankan mengikuti pelatihan untuk meningkatkan kepercayaan diri khususnya terhadap penampilan, agar dapat memiliki citra raga positf dan meningkatkan persepsi terhadap produktivitas, selain itu SPG yang telah memiliki citra raga positif agar dapat terus mengembangkan diri dengan konsep diri positif yang telah dimiliki sehingga dapat terus meningkatkan produktivitas.

Kepada supervisior, hasil dari penelitian menunjukkan bahwa citra raga memiliki hubungan yang cukup kuat dengan persepsi terhadap produktivitas penjualan, sehingga dapat disarankan bagi pihak supervisor yang bertanggung jawab kepada SPG untuk memberikan pelatihan yang positif agar dapat menumbuhkan citra raga yang positif kepada SPG. Sehingga ketika citra raga pada setiap SPG telah positif maka persepsi terhadap produktivitas penjualan juga akan semakin meningkat. Selain itu pengarahan dari supervisior sangat diperlukan untuk meningkatkan citra raga berupa dukungan motivasi terhadap penampilan fisik, sehingga SPG menjadi lebih percaya diri dan motivasi untuk berprestasinya semakin baik. Peneliti memberikan beberapa saran kepada peneliti selanjutnya yang berminat meneliti persepsi terhadap produktivitas yang ditinjau dari citra raga yaitu, peneliti selanjutnya diharapkan untuk menambah faktorfaktor lain yang dapat mempengaruhi persepsi terhadap produktivitas dan juga memperluas subjek yang menjadi sampel penelitian, sehingga mendapatkan hasil yang dapat digeneralisasikan..

\section{DAFTAR PUSTAKA}

Ariel, O. (2011). Analisis Pengaruh Kepuasan Kerja Terhadap Produktivitas Karyawan Kantor Cabang PT. Nutrifood Surabaya. Surabaya: Universitas Kristen Petra

Atkinson, J. W. (1992). Pengantar Psikologi ( Taufik, N. Trans). Jakarta :Penerbit Erlangga.

Azwar, S. (2010). Dasar-dasar Psikometri. Yogyakarta: Pustaka Pelajar

Azwar, S. (2010). Reliabilitas dan Validitas. Yogyakarta: Pustaka Pelajar.

Carter, D. (1999). Strategi Marketing. New Jersey: Prentice Hall International Inc.

Chaplin, J.P. (1999). Kamus Lengkap Psikologi. (Terjemahan Kartini Kartono). Jakarta: PT. Raja Grafindo Persada.

Chas, T. (1999) Body Image, development, deviance, and change. New York : The Guildford Press.

Chas, T. F. (2005). The norms and stability of new measure of the multidimensional citra raga construct. USA:ScienceDirect journal vol 2 199-203.

Dadang, S. (2012) Manajemen Sumber Daya Manusia. Jakarta : CAPS (Center for Academic Publishing Service).

Darmono. (1998). Manajemen Karier. Diakses: 15 November dari blog http://serunimarinda.mhs.narotama.ac.id/

Elmer, E \& Houran, J (2010) Physical Attractiveness in the Workplace: Customers Do Judge Books by Their Covers. New York: 2020 Skills. 
Gibson, I. D. (1987). Organisasi Dan Manajemen. (Terjemahan. Djoerban Wahid). Jakarta: Erlangga.

Galluci, N.T \& Meyer, R.G. (1984). People can be too perfect: Effects subject and targets attractiveness on interpersonal attraction. Psychological Reports, 55, 351-360.

Hardy, M., \& Heyes, S. (1998). Pengantar psikologi konseling (Soemardji, Trans). Jakarta: Penerbit Erlangga.

Hendrojuwono, W. (1996) Mempersiapkan manusia produktif (suatu gagasan dan usulan). Jurnal Psikologi. Jakarta: Fakultas Psikologi Universitas Indonesia

Honigman,R, \& Castle, DJ (2004) Mencemaskan penampilan. Diakses 15 Oktober 2012, dari e-psikologi: http://www.epsikologi.com/remaja/article.

Hurlock, B. E. (1999). Psikologi Perkembangan: Suatu Pendekatan Sepanjang Rentang Kehidupan. Jakarta: Penerbit Erlangga.

Jersild, A. J. (1979). Psychology of adolescence. New York: Mc William Company.

Kalat, J. (2009) Biopsikologi. Jakarta: Salemba Empat.

Kartono, K. 1985. Psikologi Sosial Untuk Manajemen Perusahaan Dan Industri. (Edisi Kedua). Jakarta: CV. Rajawali

Konstanski, M. \& Gullone, E (2007). The Impact A Teasing on Children's Body Image. British: Journal Of Child \& Family Studies, 16 (3).

Kuiniati, Y. (2004). Gangguan Makan (Eating Disorder) pada remaja. Diakses 20 Desember 2012 dari Bakrie Graduate Fellowship: http://bgfunhas.blogspot.com/2013/01/gangguan-makaneating-disorder- pada.html

Mangkuprawira, S. \& Hubeis, A.V. (2007). Manajemen Mutu Sumber Daya Manusia. Bogor: Ghalia Indonesia.

Mappiare, A. (1982). Psikologi Remaja. Yogyakarta: Usaha Nasional.

Melissa. (2009). Pengaruh Penerapan Total Quality Management terhadap Produktivitas kerja Karyawan Giant Hypermarket Botani Square Bogor. Bogor: Institut Pertanian Bogor.

Melliana, A. (2006). Menjelajahi tubuh perempuan dan mitos kecantikan. Yogyakarta: Lukis Pelangi Aksara.

Nasution. (2004). Manajemen produksi dan operasi: edisi revisi 2004. Jakarta: Ghali Indonesia.
Nitisemito, Alex. S. (2001). Manajemen Personalia. Jakarta: Ghalia Indonesia.

Prickett, R. (2007). Does Attractiveness Increase Sales Productivity?. USA: Undergraduate Paper Competition.

Purwodarminto. (1987). Kamus Bahasa Indonesia. Jakarta: Balai Pustaka.

Raharti, M. (2001). Manajemen penjualan dan pemasaran. Yogyakarta: Adi Office.

Ravianto, J. (1993). Manajemen sumber daya manusia: cetakan pertama. Yogyakarta: Gajah Mada University Press.

Rakhmat, J. 1986. Psikologi Komunikasi. Bandung: CV. Remaja Karya

Retnanigsih, R. (2001). Sales promotion girls dalam berbagai prespektif. Jakarta: Salemba Empat.

Riduwan (2009). Metode dan Teknik Menyusun Proposal Penelitian. Jakarta: Alfabeta.

Rusiemi. 1993. Peranan Citra Raga terhadap Penyesuaian Diri pada Remaja di

Sekolah Negeri I Lamongan. Yogyakarta : Fakultas Psikologi Universitas Gadjah Mada

Sachsida, A. (2005). Beauty and the Labor Market- Study one Spesific Occupation. Brasilia: Catolica University

Santoso, G (2012). Fundamental Metodologi Penelitian Kuantitatif dan Kualitatif. Jakarta: Prestasi Pustaka.

Saptowalyono, C.A. (2012). Penjualan kosmetik mencapai Rp 9,67 triliun. Kompas. Diakses pada tanggal 12 Desember 2012 dari bisniskeuangan.kompas.com/read/2012.

Savacool, J. (2000). The World Has Curves: The Global Quest for the Perfect Body. New York: Rodale.

Sedarmayanti. (2004). Mengembangkan kepribadian pegawai. Bandung: Mandar Maju.

Small, Kelly. (2001). Addressing body image, Self Esteem, and Eating Disorder. A Peer Review Journal. Diakses pada tanggal $13 \quad$ Desember 2012 dari http://people.ucalgary.ca/ egallery/volume2/small.html.

Sugiono. (2007). Metode Penelitan Kuantitatif, Kualitatif dan R\&D. Bandung: Alfabeta.

Suryabrata, S. (2000). Metodologi Penelitian. Jakarta: PT Raja Grafindo Persada

Suryanie (2005). Hubungan citra raga dengan narsisme para model. Surakarta: Fakultas Psikologi Universitas Muhamadiyah. 
Thornburg. (1982). Psychology of physical education and sport. New Delhi: B.V. Gupta.

Topan (2010). Survei Nielsen perusahaan marketing. The Jakarta Post. Diakses pada tanggal pada tanggal 12 Desember 2012 dari http://elibrary.mb.ipb.ac.id/files/disk1/22/mbipb12312421421421412-topanerosk-1073-10-r42-05-t-n.doc.

Thompson, J.K., Coovert, M. \& Stomer, S. (1999). Body image, social comparison, and eating disturbance: A covariance structure modeling investigation. International Journal of Eating Disorder, 26, 43-51.

Thompson, J.K., Heinberg, L. J., Altabe, M. N., \& Tantleff-Dunn, S. (1999). Exacting beauty: Theory, assessment and treatment of body image disturbance. Washington DC: American Psychological Association.

Usman, H. dan R. Purnomo Setiady Akbar. 2000. Pengantar Statistika. Jakarta: Bumi Aksara.

Walgito, B (2003) Psikologi Sosial. Yogyakarta: Andi. 